\title{
Analisis Faktor yang Mempengaruhi Pendapatan Petani Padi Pengguna Pupuk Organik dan Anorganik di Kecamatan Harau
}

\section{Analysis of Factors Influencing Rice Farmer Income Using Organic and Inorganic Fertilizer in Harau District}

\author{
Riva Hendriani, ${ }^{1)}$ Latifa Hanum, ${ }^{2)}$ Regia Indah Kemala Sari ${ }^{3)}$ \\ ${ }^{1}$ Politeknik Pertanian Negeri Payakumbuh, riva_hendriani.yahoo.com \\ ${ }^{2}$ Politeknik Pertanian Negeri Payakumbuh, justhanum@gmail.com \\ ${ }^{3}$ Politeknik Pertanian Negeri Payakumbuh, regia_sari@yahoo.co.id
}

\begin{abstract}
Abstrak
Penelitian ini dilatar belakangi oleh adanya ketergantungan petani menggunakan pupuk anorganik dan meningkatnya harga pupuk anorganik tersebut yang berakibat pada bertambahnya biaya produksi dan berkurangnya keuntungan usahatani padi, sehingga berpengaruh terhadap kesejahteraan keluarga petani. Berdasarkan penelitian sebelumnya diperoleh informasi bahwa terdapat perbedaan pendapatan petani padi pengguna pupuk organik dengan pendapatan petani padi pengguna pupuk anorganik di Kecamatan Harau. Oleh karena itu, tujuan dari penelitian ini adalah untuk menganalisis faktor-faktor yang mempengaruhi pendapatan petani padi pengguna pupuk organik dan anorganik di Kecamatan Harau. Penelitian ini dilakukan dengan menggunakan survey kepada petani padi di Kecamatan Harau. Analisa data dilakukan secara kuantitatif yaitu melalui analisa regresi linier berganda dan dilanjutkan dengan uji F. Berdasarkan hasil penelitian diketahui bahwa faktor yang mempengaruhi secara nyata pendapatan petani padi pengguna pupuk organik dan anorganik di Kecamatan Harau adalah: Luas lahan dan biaya produksi. Sedangkan faktor yang mempengaruhi secara tidak nyata adalah: umur petani, pendidikan petani, jumlah produksi dan harga produksi.
\end{abstract}

Kata Kunci: analisis, faktor pendapatan, petani padi, organik, anorganik

\begin{abstract}
The dependence of farmers on inorganic fertilizers and the increasing price of inorganic fertilizers has resulted in increased production costs and reduced profits from rice farming, which has an effect on the welfare of farmer families. Based on previous research, information was obtained that there were differences in income of rice farmers using organic fertilizers with the income of rice farmers using inorganic fertilizers in Harau District. The purpose of this study was to analyze the factors that influence the income of rice farmers using organic and inorganic fertilizers in Harau District. This research was conducted using a survey of rice farmers in Harau District. Data analysis was carried out quantitatively, namely through multiple linear regression analysis and continued with F test. Based on data analysis, factors that significantly influence the income of rice farmers using organic and inorganic fertilizers in Harau District are: land area and production costs. Meanwhile, factors that not significantly influence the income of rice farmers using organic and inorganic fertilizers in Harau District are: ages of farmer, educations, quantity of production and price
\end{abstract}

Keywords : analysis, income factor, rice farmers, organic, inorganic 


\section{Pendahuluan}

Penggunaan pupuk anorganik (kimia buatan) merupakan bagian integral dari sistem pertanian modern. Dalam beberapa dekade terakhir, penggunaan pupuk buatan dan input buatan pabrik lainnya cenderung meningkat secara signifikan. Namun, peningkatan ini juga disertai oleh peningkatan beberapa masalah, termasuk tekanan inflasi, degradasi ekosistem pertanian dan ancaman kerusakan lingkungan dan kesehatan manusia [1].

Agar tidak memperburuk situasi, yang dapat mengganggu keberlanjutan sistem produksi beras, upaya perlu dilakukan untuk melestarikan dan merehabilitasi sumber daya lahan yang ada, terutama sawah. Salah satu upaya yang dapat dilakukan oleh petani untuk memperbaiki kondisi ini adalah petani padi kembali menggunakan pupuk organik pada pertanian padi sawah. Kenaikan harga dan kelangkaan pupuk kimia adalah salah satu penyebab berkurangnya pendapatan petani dan menurunnya kesejahteraan petani.

Berkembangnya solusi teknologi pertanian padi organik untuk mengatasi masalah pupuk anorganik, terutama masalah kenaikan harga pupuk anorganik, telah menyebabkan sebagian kecil petani padi di Kabupaten Lima Puluh Kota mulai menggunakan teknologi pertanian organik dengan pupuk menggunakan pupuk atau kotoran hewan lainnya untuk mengurangi biaya produksi pertanian padi.

Kabupaten Lima Puluh Kota adalah salah satu daerah pertanian yang ditandai dengan indikator 60,01 persen penduduk yang bergerak di bidang pertanian. Dengan kondisi ini sektor pertanian adalah bisnis utama dalam administrasi pemerintah daerah. Di mana sektor ini menyumbang 30,09 persen dari total Lima Puluh Kota total pendapatan domestik bruto regional. Ironisnya, populasi Kabupaten Lima Puluh Kota memiliki populasi 325 ribu orang, 23 persen lebih banyak dalam kemiskinan [2].

Berdasarkan penelitian sebelumnya, diperoleh informasi tentang, pendapatan petani yang menggunakan pupuk organik adalah Rp. 657.838 - Rp. 14.633.798; Penghasilan rata-rata Rp. $5,464,104,03$. Sementara pendapatan petani padi menggunakan pupuk anorganik adalah Rp. 500.983 Rp. 14.189.743; Penghasilan rata-rata adalah $\mathrm{Rp} 5.901 .806,24$. Pendapatan petani padi menggunakan pupuk organik tidak berbeda dengan petani padi yang menggunakan pupuk anorganik [3].

Dari uraian di atas, perdebatan dalam penelitian ini adalah faktor apa yang mempengaruhi pendapatan petani padi menggunakan pupuk organik dan organik di Kabupaten Harau? Tujuan penelitian dari penelitian ini adalah untuk menganalisis faktor-faktor yang mempengaruhi pendapatan petani menggunakan pupuk organik dan anorganik di Kabupaten Harau.

\section{Metode Penelitian}

Penelitian ini dilakukan di Kecamatan Harau, Kabupaten Lima Puluh Kota. Penelitian ini dilakukan selama kurang dari 8 bulan, mulai dari April 2017 hingga November 2017. Penelitian ini menggunakan survei dengan tanya jawab langsung kepada petani di daerah penelitian. Metode survei umumnya merupakan cara untuk mengkonversi data dari unit atau individu dalam periode waktu tertentu. Dengan metode survei ini adalah mungkin untuk mendapatkan data yang memberikan gambaran umum tentang topik yang sedang dibahas [4]. Pemilihan area penelitian dilakukan dengan metode purposive atau disengaja [4]. Dua Nagari dipilih, yaitu Nagari Taram dan Nagari Sarilamak berdasarkan pertimbangan: (1) Nagari yang dipilih adalah pusat produksi beras di Distrik Harau; (2) Nagari terpilih tidak pernah melakukan penelitian tentang analisis pendapatan petani padi menggunakan pupuk organik dan pupuk anorganik.

Sampling (Metode Sampling) menggunakan metode pengambilan sampel bola salju. Metode sampling bola salju digunakan apabila tidak tersedianya data jumlah populasi sehingga tidak dimungkinkan untuk membuat kerangka sampel [5]. Dengan metode ini, peneliti mencari responden yang sesuai dengan kriteria yang ditetapkan, kemudian dari responden tersebut akan menunjuk atau mengundang orang lain untuk mengambil sampel, dan kemudian sampai jumlah sampel yang dibutuhkan oleh peneliti yang telah ditunjuk representatif untuk mencari penelitian. tujuan. Jumlah total sampel penelitian adalah 80 pengguna padi sawah menggunakan pupuk organik dan anorganik.

Data yang dikumpulkan dalam penelitian ini adalah data primer yang diperoleh dari petani responden atau petani sampel dengan melalui metode wawancara berdasarkan daftar pertanyaan/kuisioner yang telah disiapkan terlebih dahulu. Untuk menganalisa faktor-faktor yang berpengaruh terhadap pendapatan petani padi di Kecamatan Harau digunakan analisa kuantitatif. 
Analisa kuantitatif yang digunakan adalah Analisa Regresi Linier Berganda dan dilanjutkan dengan uji F. Model spesifik yang digunakan dalam penelitian ini adalah:

$$
\mathrm{Y}=\mathrm{a} 0+\mathrm{a}_{1} \mathrm{X}_{1}+\mathrm{a}_{2} \mathrm{X}_{2}+\ldots .+\mathrm{ai}_{\mathrm{i}} \mathrm{X}_{\mathrm{i}}[5]
$$

Jadi model persamaan regresi dalam penelitian ini adalah :

$$
\mathrm{Y}=\mathrm{a} 0+\mathrm{a}_{1} \mathrm{X}_{1}+\mathrm{a}_{2} \mathrm{X}_{2}+\mathrm{a}_{3} \mathrm{X}_{3}+\mathrm{a}_{4} \mathrm{X}_{4}+\mathrm{a}_{5} \mathrm{X}_{5}+\mathrm{a}_{6} \mathrm{X}_{6}
$$

dimana:

$$
\begin{array}{ll}
\mathrm{Y} & =\text { Pendapatan petanipadi(Rp) } \\
\mathrm{X} 1 & =\text { Umur (Tahun) } \\
\mathrm{X} 2 & =\text { Pendidikan (Tahun) } \\
\mathrm{X} 3 & =\text { Luaslahan }(\text { Ha) } \\
\mathrm{X} 4 & =\text { Biayaproduksi }(\mathrm{Rp}) \\
\mathrm{X} 5 & =\text { JumlahProduksipadi }(\mathrm{Kg}) \\
\mathrm{X} 6 & =\text { Hargagabah }(\mathrm{Rp} / \mathrm{Kg}) \\
\mathrm{a} 0 & =\text { Konstanta } \\
\mathrm{ai} & =\text { Koefisien regresi }
\end{array}
$$

Hubungan antara variabel terikat $(\mathrm{Y})$ dengan variabel bebas $(\mathrm{X})$, secara matematis dapat dirumuskan sebagai berikut: $\mathrm{Y}=\mathrm{f}\left(\mathrm{X}_{1}, \mathrm{X}_{2} \ldots . . ., \mathrm{X}_{6}\right)$. Dalam hal ini perlu dilakukan adalah uji Signifikasi dan analisa Regresi

$$
\begin{aligned}
& \mathrm{H}_{\mathrm{O}}= \begin{array}{l}
\text { Koefisien regresi dari variabel variabel yang mempengaruhi pendapatan tidak berbeda } \\
\text { nyata }
\end{array} \\
& \mathrm{H}_{1}=\begin{array}{l}
\text { Koefisien regresi dari variabel variabel yang mempengaruhi pendapatan } \\
\text { berbedanyata }(\mathrm{b} 1 \neq 0)
\end{array}
\end{aligned}
$$

\begin{tabular}{|c|c|c|c|c|c|}
\hline NO & Variabel & $\mathrm{db}$ & $\begin{array}{l}\text { Parameter } \\
\text { Dugaan }\end{array}$ & $\begin{array}{c}\text { Standar } \\
\text { Kesalahan }\end{array}$ & $\mathrm{t}$ hitung \\
\hline 1 & Konstanta & 1 & $-329.452,077$ & $213.886,489$ & $\overline{-1,540}$ \\
\hline 2 & Umur & 1 & 645,739 & 670,440 & 0,963 \\
\hline 3 & Pendidikan & 1 & 1371,324 & $3.042,156$ & 0,451 \\
\hline 4 & Luaslahan & 1 & $24.841 .515,356^{*}$ & $340.026,243$ & 73,058 \\
\hline 5 & BiayaProduksi & 1 & $-1,006^{*}$ & 0,007 & $-134,660$ \\
\hline 6 & JumlahProduksi & 1 & 45,029 & 69,431 & 0,649 \\
\hline 7 & HargaProduksi & 1 & 53,627 & 41,990 & 1,277 \\
\hline
\end{tabular}

Pengujian dilakukan dengan uji $\mathrm{F}$

Kriteria pengambilan keputusan : Jika F hitung > F tabel, maka Ho ditolak

\section{Hasil dan Pembahasan}

Jika $\mathrm{F}$ hitung $<\mathrm{F}$ tabel, maka $\mathrm{H}_{\mathrm{O}}$ diterima

Pendapatan petani padi di Nagari Sarilamak dan Nagari Taram Kecamatan Harau dipengaruhi oleh umur petani, pendidikan petani, luas lahan tanaman padi, biaya produksi usaha tani padi, jumlah produksi padi dan harga jual produksi gabah. Ada pun faktor-faktor yang mempengaruhi pendapatan petani padi di Nagari Sarilamak dan Nagari Taram Kecamatan Harau yang dianalisis dengan sistem regresi linier berganda disajikan dalam Tabel 1.

Tabel 1. Hasil analisis regresi linier berganda pendugaan fungsi pendapatan petani padi di Nagari Koto Tuo Kecamatan Harau

Keterangan : Variabel Ftabel $(0,05)$

t tabel $(0,05) *$ nyata pada

: Pendapatan Petani (Rp) 


$$
\begin{aligned}
& : 2,215 \\
& : 1,665=0,05
\end{aligned}
$$

Pada Tabel 4 terlihat bahwa nilai $\mathrm{F}$ hitung yang diperoleh sebesar 90.577,902, sedangkan Ftable 0,05 $(6 ; 73)$ adalah 2,215, ini berarti bahwa nilai Fhitung > Ftabel. Hal ini menunjukkan bahwa semua variabel bebas yang dianalisis berpengaruh nyata terhadap pendapatan petani padi. Koefisien determinasi yang diperoleh dari hasil analisis sebesar 1,000, artinya bahwa 100,0\% dari variabel pendapatan petani padi di Nagari Sarilamak dan Nagari Taram Kecamatan Harau dapat dijelaskan oleh variabel-variabel bebas yang ada dalam model. Dari hasil pengujian model tersebut dapat disimpulkan bahwa model yang digunakan dalam fungsi pendapatan petani padi di Nagari Sarilamak dan Nagari Taram Kecamatan Harau dapat diterima sebagai model yang baik. Berdasarkan hasil ujit, terhadap faktor-faktor yang mempengaruhi pendapatan petani padi di Kecamatan Harau adalah sebagai berikut:

\section{A. UmurPetani (X1)}

Umur petani padi secara jelas menunjukkan pengaruhyang tidaknyata terhadap jumlah pendapatan petani padi di Nagari Sarilamak dan Nagari Taram Kecamatan Harau, hal ini terlihat jelas dari hasil analisis regresi linier berganda dimana nilai t-hitungnya lebih kecil dari nilai t-tabel pada taraf nyata 5\%. Hal ini menunjukkan bahwajumlah pendapatan petani padi dipengaruhi secara tidak nyata oleh tinggi rendahnya umur dari petani padi yang ada. Kondisi ini bisa terjadi dikarenakan sebagian besar petani padi responden berada dalam usia yang produktif dan dalam kegiatan usaha tani padi mereka lebih banyak menggunakan tenaga kerja upahan. Kondisi ini menunjukkan bahwaumur petanitidak menjamin bagi petani padi untuk bisa menjalankan usaha tani padi mereka dengan sempurna dan dapat meningkatkan pendapatan usahataninya.

\section{B. Pendidikan Petani (X2)}

Berdasarkan hasil analisis regresi regresi berganda,ditunjukkan bahwa pendidikan petani berpengaruh secara tidak nyata terhadap jumlah pendapatan petani padi di Nagari Sarilamak dan Nagari Taram Kecamatan Harau. Hal ini ditunjukkan dari hasil analisis regresi berganda dimana nilai t-hitungnya lebih kecil dari nilai t-tabel pada taraf nyata5 \%. Hal ini menunjukkan bahwa peningkatan atau penurunan jumlah pendapatan petani padi dipengaruhi secara tidak signifikan oleh tinggi rendahnya pendidikan petani padi. Kondisi ini bisa terjadi dikarenakan pada umumnya pendidikan petani padi responden di Nagari Sarilamak dan Nagari Taram sebagai daerah penelitian adalah SD sampai dengan DIII, dimana mereka kurang atau tidak peduli dengan adanya inovasi baru dan mereka juga merupakan petani tradisional yang sulit untuk mengadopsi perkembangan teknologi untuk diterapkan dalam berusahatani padi mereka.

\section{Luas Lahan (X3)}

Luas lahan menunjukkan pengaruh yang nyata dan mempunyai hubungan yang positif terhadap pendapatan petani padi di Nagari Sarilamak dan Nagari Taram Kecamatan Harau. Hal ini ditunjukkan dari hasil analisis regresi berganda, dimana nilai t-hitungnya lebih besar dari nilai t-tabel pada taraf nyata 5\%, dimana koefesien regresinya 24.841.515,356. Berdasarkan hasil analisis tersebut bisa dijelaskan bahwa penambahan luas lahan tanaman padi akan menyebabkan terjadinya penambahan jumlah pendapatan petani padi dan begitu juga sebaliknya dengan asumsi ceteris paribus. Hasil analisis ini menunjukkan bahwa apabila petani padi menambah luas lahan tanaman padi seluas 1 hektar, maka akan berpengaruh secara nyata terhadap bertambahnya jumlah pendapatan petani padi sebesar Rp24.841.515,356. Kondisi tersebut bisa terjadi dikarenakan adanya tujuan petani padi menambah luas lahan sawahnya semata-mata mereka berorientasi untuk bisa menambah produksi padinya. Sehingga petani padi bisa meningkatkan pendapatan usahatani mereka.

\section{Biaya Produksi(X4)}

Biaya produksi menunjukkan pengaruh yang nyata dan mempunyai hubungan yang negative terhadap pendapatan petani padi di Nagari Sarilamak dan Nagari Taram Kecamatan Harau. Berdasarkan hasil analisis ditunjukkan bahwa nilai t-hitungnya lebih besar dari nilai t-tabel pada taraf nyata $5 \%$, dimana koefesien regresinya $-1,006$. Hal ini menunjukkan bahwa penambahan biaya produksi padi akan bisa menyebabkan terjadinya penurunan jumlah pendapatan petani padi dan begitu juga sebaliknya dengan asumsi ceteris paribus. Dari hasil analisis regresi berganda menunjukkan bahwa meningkatnya biaya produksi padi sebesar Rp 1 akan berpengaruh secara nyata terhadap menurunnya jumlah pendapatan petani padi sebesar Rp 1,006. Kondisi ini bisa terjadi 
dikarenakan bertambahnya biaya produksi padi, hal tersebut bisa menyebabkan petani padi harus menambah pengeluaran biaya terutama dalam hal pembelian sarana produksi dalam luasan lahan yang sama, akan tetapi petani padi masih belum mampu meningkatkan produksi padi mereka. Sehingga penambahan biaya produksi yang tidak diiringi dengan meningkatnya produksi padi bisa menyebabkan pendapatan petani padi menjadi berkurang atau menurun dari kondisi biasanya.

\section{E. Jumlah Produksi (X5)}

Jumlah Produksi padi secara jelas menunjukkan pengaruh yang tidak nyata terhadap jumlah pendapatan petani padi di Nagari Sarilamak dan Nagari Taram Kecamatan Harau, hal ini terlihat jelas dari hasil analisis regresi linier berganda dimana nilai t-hitungnya lebih kecil dari nilai t-tabel pada taraf nyata $5 \%$. Hal ini menunjukkan bahwa jumlah pendapatan petani padi dipengaruhi secara tidak nyata oleh tinggi rendahnya jumlah produksi dari petani padi. Hasil analisis menunjukkan bahwa meningkatnya jumlah produksi padi sebesar $1 \mathrm{~kg}$ akan berpengaruh secara tidak nyata terhadap peningkatan jumlah pendapatan petani padi hanya sebesar $\mathrm{Rp} 45,03$. Hal ini jelas bahwa bertambahnya jumlah produksi padi yang diperoleh petani walaupun dengan harga yang sama secara otomatis akan meningkatkan penerimaan petani,karena jumlah penerimaan petani padi merupakan nilai dari hasil perkalian produksi dengan harga produksi yang berlaku, sehingga semakin tinggi produksi maka akan semakin tinggi pula penerimaan petani. Sehingga dengan penambahan penerimaan petani akhirnya akan mempengaruhi bertambahnya pendapatan petani padi tersebut.

\section{F. Harga Produksi (X6)}

Harga Produksi padi secara jelas menunjukkan pengaruh yang tidak nyata terhadap jumlah pendapatan petani padi di Nagari Sarilamak dan Nagari Taram Kecamatan Harau, hal ini terlihat jelas dari hasil analisis regresi linier berganda dimana nilai t-hitungnya lebih kecil dari nilai t-tabel pada taraf nyata $5 \%$. Hal ini menunjukkan bahwa jumlah pendapatan petani padi dipengaruhi secara tidak nyata oleh tinggi rendahnya harga jual produksi dari petani padi. Hasil analisis menunjukkan bahwa meningkatnya harga produksi gabah sebesar $\mathrm{Rp} 1 / \mathrm{kg}$ akan berpengaruh nyata terhadap peningkatan jumlah pendapatan petani padi sebesar Rp53,626. Hal ini jelas bahwa harga produksi merupakan faktor penentu dari besar kecilnya penerimaan yang diperoleh petani karena harga produksi merupakan nilai dari suatu produk atau barang. Sehingga semakin tinggi harga produksi yang berlaku akan menyebabkan semakin tinggi pula penerimaan petani yang akhirnya akan meningkatkan pendapatan yang diterima oleh petani.

\section{Kesimpulan}

Faktor yang mempengaruhi secara nyata pendapatan petani padi di Kecamatan Harau adalah: Luas lahan dan biaya produksi. Sedangkan faktor yang mempengaruhi secara tidak nyata pendapatan petani padi adalah: umur petani, pendidikan petani, jumlah produksi dan harga produksi.

\section{Daftar Pustaka}

[1] Salikin, K.A, 2003. Sistem Pertanian Berkelanjutan. Kanisius, Yogyakarta.

[2] Badan Pusat Statistik Kabupaten Lima Puluh Kota. 2016. Kabupaten Lima Puluh Kota dalam Angka. Sarilamak.

[3] Hendriani, Riva. 2018. Analisis Pendapatan Petani Padi Pengguna Pupuk Organik dan Anorganik di Kecamatan Harau. Jurnal Lumbung Vol. 17 No. 2 Juli 2018. http://jurnalpolitanipyk.ac.id/index.php/LUMBUNG/article/view/37/28

[4] Singarimbun M, 2011. Metode Penelitian Survei. Lembaga Penelitian. Pendidikan dan Penerangan Ekonomi dan Sosial. Jakarta.

[5] Sugiyono. 2013. Metode Penelitian Kuantitatif dan Kualitatif dan R \& D. Alfabeta. Bandung.

[6] Rianse, Usman dan Abdi. 2010. Metodologi Penelitian Sosial dan Ekonomi-Teori dan Aplikasi. Penerbit Alfabeta. Bandung.

[7] Dinas Tanaman Pangan dan Hortikultura Kabupaten Lima Puluh Kota, 2009. Laporan Tahunan 2015. Harau. 